\title{
Program Pemberdayaan Ibu RT Usaha Mandiri Dalam Bidang Pembuatan Kue Kering Dan Basah Kelompok Ibu Kasihan Sejahtera
}

\author{
Nano Prawoto, Agus Tri Basuki \\ Program Studi Manajemen, Fakultas Ekonomi dan Bisnis, Universitas Muhammadiyah Yogyakarta \\ Email : nanopra@umy.ac.id \\ DOI: $10.18196 / p p m .32 .227$
}

\begin{abstract}
ABSTRAK
Program ini didasarkan pada fakta empiris bahwa kehidupan sosial ekonomi masyarakat Kasihan RTo2, Tamantirto, Kasihan, Bantul rendah. Persoalannya adalah masih rendahnya kemampuan masyarakat dalam meningkatkan penghasilan keluarga, padahal lokasi tempat tinggal sangat strategis. Program ini bertujuan untuk meningkat pengetahuan masyarakat Kasihan RTo2 Tamantirto Kasihan Bantul agar memiliki kemandirian dan kemampuan untuk meningkatkan kesejahteraan kelvarga. Program ini menggunakan metode pelatihan, yaitu pembuatan Kue basah dan kue kering baik teori dan praktik, penyajian serta manajemen usaha. Pelatihan ini diikuti oleh 11 ibu rumah tangga baik yang belum punya usaha maupun yang sudah berusaha. Target dari program pelatihan ini adalah meningkatkan kapasitas SDM dalam kemampuan produksi kue untuk menciptakan usaha baru dan juga diversifikasi produk bagi yang telah melakukan usaha. Kemudian outcome yang diharapkan dalam pelatihan ini adalah meningkatnya penghasilan keluarga dari usaha peserta Kelompok lbu Kasihan Sejahtera. Melalui peningkatan penghasilan dari berjualan kue tradisional tersebut mereka akan mampu memenuhi kebutuhan hidupnya sehari-hari, termasuk mampu menyekolahkan anakanaknya bahkan hingga ke perguruan tinggi, serta memiliki tabungan di Bank untuk masa depannya.
\end{abstract}

Kata Kunci : Kue Tradisonal, Pelatihan dan Kesejahteraan

\section{PENDAHULUAN}

Makanan tradisional adalah makanan yang berasal dari suatu daerah tertentu yang memberikan ciri khas pada suatu daerah. Makanan tradisional sering disajikan pada acara-acara yang masih memberikan kesan adanya unsur adat, seperti acara pernikahan, acara khitanan, upacara adat, maupun upacara keagamaan (Rochani, 2007:6). Makanan tradisional di beberapa daerah di Indonesia dipengaruhi oleh kebiasaan makan masyarakat dan menyatu di dalam sistem sosial budaya berbagai golongan. Makanan tersebut disukai, karena rasa, tekstur, dan aromanya sesuai dengan seleranya. Makanan tradisional juga mengandung segi positif seperti: bahanbahan yang alami, bergizi tinggi, sehat dan aman, murah, dan mudah didapat, serta sesuai dengan selera masyarakatnya. Dengan beragam dan bervariasinya bahan dasar, maka dapat dihasilkan bermacam-macam jenis makanan tradisional yang lezat dan memiliki gizi seimbang.

Terdapat suatu ungkapan yang menyatakan bahwa sekali-kali jangan pernah mengatakan telah berkunjung ke suatu daerah jika belum mencoba makanan khas dari daerah tersebut, ungkapan ini juga berlaku di Yogyakarta. Dengan hadirnya berbagai jenis produk makanan impor seperti, brownies, roti, Dunkin' Donuts, pizza hut, hamburger, pancake, dan cake, yang tersebar di berbagai sudut kota Yogyakarta, menjadikan kue tradisional mengalami penurunan produktivitas. Hal ini terjadi karena kebanyakan masyarakat lebih memilih menggunakan kuekue modern sebagai sajian makanan dalam setiap acara yang dilakukan. Sebagai contoh: saat acara-acara seminar, pelatihan, ataupun perayaan ultah, orang-orang lebih memilih brownies, atau roti sebagai sajian makanannya. Sedangkan untuk kue-kue tradisional, hanya dapat kita 
temui pada acara-acara yang masih memberikan kesan adanya unsur adat, seperti pernikahan, arisan, pengajian, hajatan, dll.

Secara internal dalam persaingan dunia usaha layanan makanan, masih tersimpan sejumlah persoalan kebudayaan. Dalam kehidupan sehari-hari masyarakat dihadapkan pada semakin banyaknya jasa layanan makanan modern bermunculan yang menyajikan hidanganhidangan makanan impor, modern, nuansa yang bersih, nyaman, dan tampilan yang menarik. Semuanya dikemas dalam penerapan konsep yang efisien dan efektif. Pada era globalisasi, tuntutan terhadap mutu produk akan semakin tinggi disertai dengan harga yang semakin bersaing. Keberhasilan suatu usaha dalam pasar terbuka ditentukan oleh produktivitas dan efisiensi produksi. Agar dapat bertahan dan berkembang secara berkelanjutan, setiap bagian dalam usaha itu melaksanakan pekerjaannya dan menunjuk pada tanggung jawab yang diemban oleh para pelaku usaha baik itu pedagang kecil maupun pengusaha besar.

Pengetahuan mengenai cara berjualan atau memperdagangkan produk menjadi penting bagi para pedagang kue tradisional saat dihadapkan pada beberapa permasalahan, seperti menurunnya pendapatan yang disebabkan oleh menurunnya daya beli konsumen terhadap suatu produk sehingga mengakibatkan lambatnya pertumbuhan dalam kegiatan berdagang. Globalisasi telah mengubah peta perdagangan dunia. Pasar yang semakin terbuka membuat persaingan semakin ketat dan melahirkan hiperkompetisi. Dengan semakin banyaknya kue-kue modern yang masuk ke daerah, bukan hanya menyebabkan punahnya beberapa kue tradisional yang terganti kedudukannya, namun juga berpengaruh pada perekonomian para pedagang kue tradisional yang semakin menurun. Untuk menghadapi persaingan dengan produk kue impor, maka para pedagang kue tradisional memerlukan beberapa upaya atau strategi yang harus dilakukan agar kue tradisional juga tetap menjadi khas dari daerahnya atau tidak mengalami kepunahan dan juga untuk mempertahankan perekonomian mereka agar tetap stabil.

Saat ini masyarakat sudah mulai sadar bahwa dengan mengkonsumsi makanan tradisional merupakan bagian dalam meningkatkan produksi makanan lokal dan membantu menyelesaikan masalah pengangguran dan kemiskinan. Dengan mengkonsumsi makanan tradisional khususnya kue akan membantu peningkatan perekonomian kawasan. Secara umum dikenal 3 jenis kue yang masing-masing memiliki karakteristik berbeda. Ketiga jenis kue tersebut adalah (Rati, 2013), a. Kue basah adalah istilah yang digunakan untuk menyebut kue yang bertekstur lembut, empuk, dan relative basah. Kue jenis ini biasanya memiliki umur simpan yang pendek karena kadar airnya tinggi di bandingkan kue-kue yang lain. Kue basah identik dengan kue tradisional atau kue oriental. Hal ini karena umumnya kue tradisional terbuat dari tepung beras, gula, dan santan, sehingga lekas basi. Kue basah biasanya dimasak dengan cara dikukus, direbus, atau digoreng; b.Kue Kering merupakan istilah yang di gunakan untuk menyebut kue yang teksturnya keras dan renyah karena memiliki kadar air yang sangat minim. Kue kering mempunyai daya simpan yang sangat tinggi. Bahannya bisa dari apa saja,tepung beras, tepung ketan, terigu ataupun sagu. Cara memasaknya biasanya di goreng atau di panggang dalam oven. Kue kering yang dioven biasanya di sebut cookies; c. Bakery merupakan istilah yang digunakan untuk menyebut penganan yang berupa roti, cake, pastri, dan sejenisnya. Disebut bakery karena penganan ini dimasak dengan cara di panggang. Bahan dasar bakery 
selalu sama, yaitu tepung terigu, lemak, gula, telur, garam dan cairan, baik yang berupa air ataupun susu.

Kasihan RT 02 Tamantirto Kasihan Bantul adalah salah satu kawasan yang sangat strategis karena dekat dengan jalan Bibis Raya. Berikut ini profil Kasihan RT02 sebagai berikut ; 1) RT 02 kasihan memiliki $70 \mathrm{KK}$ dan lebih dari 50 persen berpenghasilan rendah; 2) 70 persen ibu-ibu tidak bekerja atau tidak memiliki penghasilan; 3) sebagian besar kepala keluarga 90 persen berpendidikan SMA ke bawah; 4) lokasi RT 02 strategis pinggir jalan Bibis Raya; 5) Lokasi sekitar kasihan banyak mahasiswa kos (mahasiswa UMY, Stikes Alma Atta, STIE Hampara); 6) kasihan merupakan kawasan berkembang cepat untuk kawasan perumahan. Salah satu cara untuk mengatasi persoalan rendahnya pendapatan masyarakat Kasihan tersebut adalah dengan konsep mata pencaharian dalam memahami Coping Strategies karena merupakan bagian dari strategi mata pencaharian (Livelihood Strategies). Coping Strategies dapat dikelompokkan menjadi tiga kategori, antara lain (Suharto, 2009:31): a) Strategi aktif, yaitu strategi yang mengoptimalkan segala potensi keluarga untuk melakukan aktivitas sendiri, memperpanjang jam kerja, memanfaatkan sumber atau tanaman liar di lingkungan sekitar, dan sebagainya. b) Strategi pasif, yaitu mengurangi pengeluaran keluarga, misalnya; pengeluaran untuk biaya sandang, pangan, pendidikan, dan sebagainya. c) Strategi jaringan, misalnya menjalin relasi, baik secara informal maupun formal dalam lingkungan sosialnya dan lingkungan kelembagaan, sebagai contoh; meminjam uang tetangga, mengutang ke warung, memanfaatkan program anti kemiskinan, meminjamkan uang ke rentenir atau bank, dan sebagainya.

\section{TUJUAN DAN MANFAAT}

\section{Tujuan}

Tujuan dari kegiatan pengabdian kepada masyarakat ini adalah untuk memberikan pengetahuan dan keterampilan (skill) pembuatan kue tradisional yang layak jual kepada masyarakat Dusun Kasihan Rt. 02, Desa Tamantirto, Bantul tentang produksi kue tradisional

\section{Manfaat}

Manfaat yang didapat dari pengabdian kepada masyarakat ini adalah dapat menambah pengetahuan dan kemampuan masyarakat khususnya ibu rumah tangga di Dusun Kasihan Desa Tamantirto untuk memproduksi kue tradisional dan mengembangkan peluang usaha baru dan yang sudah ada.

\section{PELAKSANAAN KEgiatAN}

Sasaran dalam kegiatan pengabdian ini adalah ibu-ibu kelompok Kasihan Sejahtera di lingkungan Kasihan Rt 02 Tamantirto Kasihan Bantul. Kegiatan dalam pengabdian ini berbentuk pelatihan pembuatan kue (basah dan kering) serta cara penyajian yang menarik melalui pengepakan kepada ibu-ibu kelompok Kasihan Sejahtera di lingkungan Kasihan Rt 02 Tamantirto Kasihan Bantul. Peserta pelatihan berjumlah 11 ibu-ibu Kelompok Kasihan Sejahtera dan dilaksanakan selama 1 hari penuh. Pelatihan dimulai sejak pagi diawali 
dengan pembukaan pemilik program dan dilanjutkan dengan penjelasan-penjelasan mengenai teori pembuatan kue Bingka Kalimantan dan Kue Putri Salju. Tahapan berikutnya pada siang hari dilaksanakan praktik langsung dengan dibimbing pelatih atau nara sumber. Bahan pembuatan Kue Bingka Kalimantan meliputi (Rahman, 2015) : tepung terigu, telur, santan, gula pasir, garam dan Tapai. Kemudian untuk bahan Kue Putri Salju antara lain : campuran halus tepung terigu, maizena, mentega atau margarine, dan kuning telur. Contoh pembuatan kue Bingka Kalimantan tersebut disajikan dalam video dan dapat di lihat pada link:

https://drive.google.com/file/d/1VNxSwZroGtVllluQMfRCL0Tw5wq59dMr/view?usp=sharing

\section{HASIL DAN IMPLIKASI}

Masyarakat khususnya kelompok ibu-ibu Kasihan Sejahtera tidak mungkin akan sejahtera dengan sendirinya, tapi memerlukan usaha dan perjuangan yang terus menerus sesuai dengan Surat ArRa'd (13) ayat 11. Apabila kita hendak mengubah tingkah laku manusia yang rendah menjadi luhur, maka tidak ada jalan lain kecuali harus mengubah mafhūm-nya terlebih dahulu.

Dalam hal ini, Allah SWT berfirman:

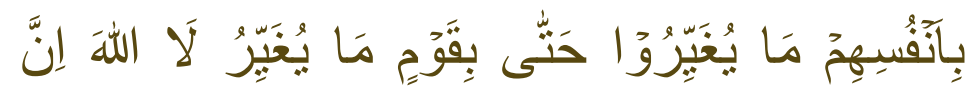

"Sesungguhnya Allah tidak akan mengubah keadaan suatu kaum, sebelum kaum itu sendiri mengubah apa yang ada pada diri mereka" (Ar-Ra'd [13]: 11).

Menjalankan bisnis kue tradisional bukanlah perkara mudah di tengah gempuran aneka kue modern yang kemasannya amat menggugah selera. Bisnis kue tradisional memiliki prospek bisnis kue rumahan cukup menjanjikan bila mampu dikelola dengan baik. Bila produsen kue tradisional mampu mengatasi 5 kendala. Lima kendala yang kerap ditemui untuk mengembangkan bisnis sekaligus mempertahankan kue tradisional adalah sebagai berikut : 1. Promosi dan Pemasaran Promosi dan pemasaran kue masih sangat terbatas. Promosi yang dilakukan usahanya masing terbilang konvensional yakni dari mulut ke mulut di mana kualitas produk yang menjadi jaminan. Adapun pemasaran masih terbatas dan belum memanfaatkan dunia maya untuk menjual produknya lantaran kue tradisional belum cukup menjual bila tidak dikemas dengan baik. 2. Kemasan Produk Kemasan produk merupakan masalah klasik bagi para pengusaha kecil dalam pengembangan bisnis. Untuk memperbaiki kemasan produknya dibutuhkan dana yang tidak sedikit atau jaringan kemitraan untuk memperoleh kemasan menarik. 3. Akses Pendanaan Seperti halnya saat mulai merintis usaha, pendanaan juga penting dalam pengembangan bisnis. Untuk 
memodernisasi peralatan produksi dan beragam item peningkatan pemasaran dan produksi tentunya membutuhkan dana besar. Karena itu, pihak perbankan dan pemerintah lebih peduli terhadap pelaku usaha kecil yang tengah mencoba mengembangkan bisnisnya. 4 . Keterbatasan SDM Pengembangan bisnis harus ditunjang SDM yang berkualitas. Untuk merealisasikan hal tersebut diperlukan upaya pelatihan peningkatan kapasitas. Selain peningkatan kualitas, kuantitas SDM diperlukan seiring peningkatan produksi usaha. 5. Dukungan Pemerintah Belum Maksimal Dukungan pemerintah berpengaruh pada pengembangan bisnis lantaran pemerintah memiliki program-program yang sejalan dengan pengembangan UKM. Pemerintah tidak sekadar menggelar pelatihan seremonial, melainkan melakukan pendampingan terhadap UKM.

Beragam permasalahan yang dihadapi UKM diharapkan bisa difasilitasi oleh pemerintah untuk dicarikan solusi. Strategi yang tepat untuk mengatasi permasalah tersebut adalah memberdayakan ibu-ibu kelompok Kasihan Sejahtera, melalui kewirausahaan dalam bidang pembuatan kue (basah maupun kering). Sehingga pemberdayaan sumber daya mereka melalui peningkatan ketrampilan khusus pembuatan kue tradisional (basah maupun kering). Dengan pelatihan ini masyarakat sangat antusias dan bersemangat untuk berlatih dan meningkatkan kemampuan baik secara teori dan praktik. Bekal pengalaman membuat kue dalam pelatihan ini menjadi modal utama untuk mendirikan usaha baru atau menambah jenis produk bagi ibu-ibu yang sudah mempunyai usaha.

Program pengabdian masyarakat ini sudah memberikan bekal yang cukup bagi masyarakat untuk berusaha, namun pemerintah daerah melalui kelurahan atau dana desa seharusnya juga mendukung program ini untuk tindak lanjut terutama berkaitan dengan permodalan. Melihat masyarakat kasihan yang rata-rata pendapatan masih relative rendah maka stimulan permodalan menjadi penting untuk mengawali usaha mandiri tersebut.

Kemudian program pengabdian masyarakat selanjutnya sangat perlu dilaksanakan Kembali sebagai tindak lanjut terutama berkaitan dengan penggalian permodalan, pemasaran konvensional dan berbasis digital dan juga berkaitan dengan model usaha, kemasan berusaha yang dapat menarik konsumen banyak.

\section{KESIMPULAN}

Dari uraian pemasalah dan solusi permasalahan dalam pengabdian masyarakat tersebut, dapat ditarik kesimpulan sebagai berikut :

1. Meningkatnya skill peserta dalam pembuatan kue kering dan basah,

2. Meningkatnya motivasi berwirausaha kue tradisional dilingkungannya

3. Menambah diversifikasi dan referensi produk untuk usaha 


\section{DAFTAR PUSTAKA}

Rochani, Siti. 2007. Cara Membuat Kue Serabi. Cibitung, Jawa Barat: Ganeca Exact.

https://www.wartaekonomi.co.id/read130451/lima-kendala-pengembangan-bisniskuetradisional.html. Diakses pada 10 Januari 2020

Suharto, Edi. 2009. Membangun Masyarakat Memberdayakan Rakyat: Kajian Strategis Pembangunan Kesejahteraan Sosial.Bandung; Refika ADITAMA Rati,

Rati, Isna. 2013. Kue adalah:Pengertian dan Definisi(online) dapat dilihat di: http://www.kamusq.com201311kue-adalah-pengertian-dan-definisi.html. Diakses pada 10 Januari 2020

Rahman, Naufal Al. 2015. "Resep Bingka Pisang, Jajan Tradisional yang Empuk dan Lembut di Mulut". IDN Times. Diakses tanggal 2 Agustus 2020. 